\title{
Arthropod distribution on an alpine elevational gradient: the relationship with preferred temperature and cold tolerance
}

\author{
ALAN BUSE $^{1 *}$, DAVID HADLEY ${ }^{1}$ and TIM SPARKS ${ }^{2}$ \\ ${ }^{1}$ Centre for Ecology and Hydrology Bangor, University of Wales, Deiniol Road, Bangor, Gwynedd, UK; \\ ${ }^{2}$ Centre for Ecology and Hydrology Monks Wood, Monks Wood, Abbots Ripton, Huntingdon, UK.
}

\begin{abstract}
Key words. Preferred temperature, optimal temperature, supercooling point, altitude gradient, mountain, Coleoptera, Byrrhidae, Carabidae, Elateridae, Opiliones
\end{abstract}

\begin{abstract}
The distribution of arthropod species on a $400 \mathrm{~m}$ elevational gradient (equivalent to a temperature decrease of $2.5^{\circ} \mathrm{C}$ ) on Snowdon, North Wales, was examined and compared with the British distribution. Preferred temperature, an indication of optimal body temperature $\left(\mathrm{T}_{\mathrm{b}}\right)$, and supercooling point (SCP), an indication of cold tolerance, of several species on the gradient were determined experimentally. The alpine beetle species Patrobus assimilis and Nebria rufescens had low preferred $\mathrm{T}_{\mathrm{b}}$, of 5.6 and $7.1^{\circ} \mathrm{C}$ respectively, whereas the more widespread upland species had higher preferred $\mathrm{T}_{\mathrm{b}}$, between 12.9 and $15.5^{\circ} \mathrm{C}$. The SCP of both alpine and widespread beetles were similar, being between -6.9 and $-5.8^{\circ} \mathrm{C}$. The alpine species, which were smaller, were freeze intolerant, whereas the widespread species, which were larger, were freeze tolerant. On the national scale there was significant correlation between preferred $T_{b}$ and species elevation, but no correlation with SCP. It is concluded that the alpine species survive on Snowdon because their optimal $T_{b}$ is close to the ambient temperature at the time of day and year when they are active and because they are able to tolerate winter temperatures, by a combination of cold tolerance and shelter. Although a species' optimal niche will tend to shift upwards as mean temperatures rise with global climatic change, complex microclimatic and biotic factors make changes in distribution difficult to predict.
\end{abstract}

\section{INTRODUCTION}

The distribution of a species within its historical range is usually connected with certain, more or less narrowly defined, habitat conditions (Uvarov, 1931); thus, "mountain" carabids tend to occur at higher elevations and at northerly latitudes (Luff, 1998). Despite temperature being only one component of the environmental factors (weather, food, other organisms and a place in which to live (Andrewartha \& Birch, 1954)) which interact with the physiology and behaviour of a species to determine its distribution, there is evidence that increasing global temperature is resulting in species shifting northward and to higher elevations (Parmesan, 1996; Parmesan et al., 1999). Potential migration rates of insects are considered to be sufficiently fast to track such changes (Lawton, 1995).

This study investigates the involvement of preferred temperature, i.e. the temperature selected in the laboratory (e.g. Herter, 1926; Thiele, 1964; Thiele \& Lehmann, 1967; Laudien, 1973), and cold tolerance, i.e. the ability to survive at low temperature (e.g. Block, 1990; Lee \& Denlinger, 1991; Leather et al., 1993; Sømme, 1999), in the elevational distribution of selected arthropod species. The selected $400 \mathrm{~m}$ elevational gradient on Snowdon in North Wales is in the alpine zone, i.e. above the timber line; in Britain, because deforestation occurred c. 2000 years ago (Birks, 1988), this zone above the potential tree line is frequently termed "montane" (Ratcliffe \& Thompson, 1988). The gradient provides a theoretical mean temperature difference of $2.5^{\circ} \mathrm{C}$ between its limits, given a decline of $0.6^{\circ} \mathrm{C}$ per $100 \mathrm{~m}$ (Mani \& Giddings, 1980 ; Lennon \& Turner, 1995). This is similar to the predicted increase in temperature due to global warming in the next 100 years (IPCC, 1996). The elevational distribution is compared with the British distribution of each species, particularly in relation to elevation and temperature.

Although the preferred temperatures of many arthropod species are related to their habitats (Herter, 1953; Thiele, 1977), the reason was unclear and so the measure fell into disrepute. Its relevance is supported by Cossins \& Bowler (1987). Because a species' physiological performance is optimal at or near a specific temperature, then body temperature $\left(T_{b}\right)$ is more relevant than environmental temperature $\left(T_{a}\right)$. Thus, its preferred $T_{b}$ and optimal $T_{b}$ [at which individuals leave most descendants (Begon et al., 1990)] are likely to be coincident. Consequently, in an ideal temperature gradient, such as fresh water (Christie \& Regier, 1988), an individual will select a $\mathrm{T}_{\mathrm{a}}$ that results in a specific $T_{b}$. Although a species might have optimal performance over a wide range of body temperatures, the influence of biotic factors, such as food availability, predation and competition, might result in a narrower niche than expected. Similarly, optimization of the balance between costs and benefits may necessitate a change, by acclimatization, in preferred $\mathrm{T}_{\mathrm{b}}$ from the optimal.

\footnotetext{
* Corresponding author. Centre for Ecology and Hydrology Bangor, University of Wales, Deiniol Road, Bangor, Gwynedd, LL57 2UP, UK; e-mail: abus@ceh.ac.uk
} 
To some extent, arthropods survive winter cold by occupying insulated microhabitats, such as grass tussocks (Luff, 1965) or leaf litter (Danks, 1991); in the mountains, they occupy cavities under stones, or crevices in rocks or in the soil (Mani, 1980). Snow is a particularly important insulator (Strathdee \& Bale, 1998). Extreme cold can be survived by freeze avoidance (intolerance) or freeze tolerance (Bale 1993; Sinclair, 1999; Sømme, 1999). In the former, freezing, which is lethal, is avoided by supercooling, although non-freezing mortality and sub-lethal injury may occur above the supercooling point (SCP) (Strathdee \& Bale, 1998). In freeze tolerant species, which are less common, freezing is restricted to the body fluids around the cells, which thereby remain undamaged (Block, 1990). SCP often represents the lower limit of survival in freeze intolerant species (Sømme, 1999) whereas freeze tolerant species may survive much lower temperatures. As with preferred $T_{b}$, the effect of a specific temperature will vary with the stage in the life cycle and acclimatization.

This study concentrates on Carabus problematicus Herbst, Nebria rufescens (Ström), Notiophilus germinyi Fauvel and Patrobus assimilis Chaudoir (Coleoptera: Carabidae); Byrrhus pilula (L.) (Coleoptera: Byrrhidae); Hypnoidus riparius (Fabricius) (Coleoptera:); and Mitopus morio (Fabricius) (Opiliones: Phalangiidae). These arthropod species are common in other alpine regions of Europe also, for example, in Norway (Østbye, 1969; Solhøy et al., 1975; Ottesen, 1985). The hypothesis tested is that species at higher elevations have lower optimal $\mathrm{T}_{b}$ (measured as preferred $\mathrm{T}_{\mathrm{b}}$ ) and greater cold tolerance than species at lower elevations. The results are compared with the British distribution of the species.

\section{MATERIALS AND METHODS}

\section{Study sites}

The elevational gradient is on a north-facing, broadshouldered ridge extending from $610 \mathrm{~m}$ to $1085 \mathrm{~m}$ on Snowdon (Yr Wyddfa) in North Wales. It is bordered by crags and glacial cirques (Campbell \& Bowen, 1989) and has areas of bouldery glacial terrain. The mean annual rainfall, recorded nearby between 1945 and 1965, was $3820 \mathrm{~mm}$ (Perkins, 1978). The tree-line is estimated to have been at $635 \mathrm{~m}$ (Birks, 1988) and so the main study sites, at $660,860,980$ and $1055 \mathrm{~m}$, are in the alpine zone. All sites are in "montane" Festuca grassland, which accounts for about $6 \%$ of the British alpine zone (Thompson \& Brown, 1992). The area is grazed by sheep from about May to early October. Boulders and surface stones provide shelter for arthropods.

\section{Preferred $\mathbf{T}_{\mathbf{b}}$}

Preferred $T_{b}$ was measured on a thermal gradient $(-4$ to $+35^{\circ} \mathrm{C}$ ) along a $100 \times 10 \mathrm{~cm}$ aluminium bar bedded in polystyrene foam, supporting a double-glazed glass cover $2 \mathrm{~cm}$ above the bar. The bar was heated at one end, by ten $10 \mathrm{ohm}, 11$ watt, ceramic-bodied resistors controlled via a transformer by a variable voltage source, and cooled at the other by four thermoelectric, 50-watt cooling modules, attached to heat sinks with the fins force-cooled. Temperatures were recorded by eleven thermocouples set into the bar at $10 \mathrm{~cm}$ intervals and by four sensors positioned $2 \mathrm{~mm}$ above the bar.

Invertebrates collected from the five sites (origins) on the field gradient in June and September 1992 were acclimated at about $8^{\circ} \mathrm{C}$ (close to mean field temperature) for at least five days. Each experimental "run" involved introducing individuals of one species on to the thermal bar and, after $30 \mathrm{~min}$, recording the position (later converted to its equivalent temperature) at which each had settled. The number of individuals introduced in each run depended on the size and availability of the species; the difference in numbers was taken into account in the analysis. To prevent starting temperature affecting the final temperature selected, approximately equal numbers of "runs" were initiated at each of three positions, labelled $\mathrm{A}$ (about $\left.5^{\circ} \mathrm{C}\right), \mathrm{B}\left(15^{\circ} \mathrm{C}\right.$ ) and $\mathrm{C}\left(25^{\circ} \mathrm{C}\right)$. The order of testing species and of starting positions were, depending on availability, randomised. The bar and air temperatures were recorded at the start and end of each run. As the species were predominantly nocturnal, and to preclude response to uneven light, all runs were in the dark.

The availability and size of the species resulted in the number of individuals introduced in each "run" varying from one to 17. Adults of $C$. problematicus, $N$. rufescens, $P$. assimilis, $N$. germinyi, B. pilula, H. riparius and M. morio, and larvae of C. problematicus were used. There was no evidence from preliminary experiments, or runs with differing numbers of individuals, that interactions had a significant effect on the results. Although aluminium is an unnatural substratum for the arthropods, it provides a consistent temperature gradient for all species and enables thorough cleaning between runs.

\section{Cold tolerance}

Specimens collected from March to September 1994, during twice weekly searches at each site, were retained in the field in small, open-top cages $(180 \times 180 \times 100 \mathrm{~mm}$, floor $50 \%$ capillary matting, containing soil, vegetation and stones, covered in "Agro-fleece" and buried to soil level). They were transferred, at field temperature, to the laboratory in June and September 1994, and in February 1995

Supercooling was determined by the method of Worland et al. (1992). The arthropod being tested was carefully inserted into a tapering plastic vial, secured near the apex with foam plastic and a thermocouple attached, using petroleum jelly. On inserting the tube into a cooling bath, the monitored temperature was stabilised briefly at $8^{\circ} \mathrm{C}$ and a controlled rate of cooling of $1^{\circ} \mathrm{Cmin}^{-1}$ applied, the preset lower limit being $-40^{\circ} \mathrm{C}$. An individual was considered to have survived freezing if it showed voluntary mobility for a period of $24 \mathrm{hr}$ following transfer to $0^{\circ} \mathrm{C}(3 \mathrm{hr}), 4^{\circ}(3 \mathrm{hr})$ and finally $11^{\circ} \mathrm{C}$ (permanently).

\section{Arthropod distribution}

At each site, ten pitfall traps $(55 \times 55 \mathrm{~mm}$, containing $10 \mathrm{~mm}$ of ethanediol) were inserted at $1 \mathrm{~m}$ intervals in a row from east to west. A large stone, supported on smaller stones, above each trap prevented disturbance by animals. Weather permitting, the traps were emptied weekly from July to October 1989 and April to October 1990. The limitations of pitfall trapping are well known (e.g. Adis, 1979; Buse, 1988; Halsall \& Wratten, 1988; Vandenberghe, 1992), the main advantages being continuous sampling and economy of labour. The influence of differential behaviour and activity were avoided by collecting in one habitat only and by making only intraspecific comparisons.

The British distribution of the relevant species was determined from the records of the Biological Records Centre (Centre for Ecology and Hydrology Monks Wood). Presence or absence of each species from the $276310 \mathrm{~km}$ squares containing $\leq 98 \%$ sea were recorded, together with the mean elevations, mean winter and summer temperature, and mean hours of sunshine in these squares.

\section{Temperature measurements}

Because the study spanned several years, site temperature records are intended only to assist in interpreting results, rather 
than to identify detailed correlations. From mid-July to midOctober 1990, the maximum and the minimum temperature for each week at each site were recorded, within a $0.5 \mathrm{~m}$ radius, in shaded turf, in sun-exposed turf, and under a boulder. One maximum and one minimum reading were retrieved for the winter period from November 1990 to March 1991. Throughout 1991, daily changes in temperature were monitored at $15 \mathrm{~min}$ intervals at the 660 and $860 \mathrm{~m}$ sites, using "Icespy" temperature loggers (Silvertree Engineering Ltd).

\section{Statistical analysis}

The statistical analysis in the preferred $\mathrm{T}_{b}$ experiment concentrated on the mean temperature, and its standard deviation, from each run, using a general linear model with origin as a categorical variable. Weighted regression, where weights were the numbers of individuals in each run, was used. For each species, the mean preferred $T_{b}$ from each run was analysed to examine the differences between the origins and any $\mathrm{A} / \mathrm{B} / \mathrm{C}$ effect. The analysis of standard deviation was, obviously, restricted to those runs containing $>1$ individuals. A comparison of the species for both mean temperature and standard deviation was made by weighted regression, using the mean or the standard deviation from each run. The latter measure is an indication of the spread along the temperature gradient and, as such, is a measure of temperature specificity. The comparison between origins and species was made on the basis of least square (predicted) means.

In the supercooling experiments, one-way ANOVA was used to compare the SCPs of the species and to examine the effect of elevation and season on the results.

The significance of the differences in the counts of a species at different elevations on the elevational gradient was tested for each species individually using a Chi-squared test, with a null hypothesis that counts did not differ at each elevation.

Pearson correlation was used to test the relationship between $\mathrm{T}_{\mathrm{b}}$, SCP and the mean elevation, mean summer temperature and mean winter temperature of the British distribution of several species. Spearman's rank correlation was used to test the relationship between the temperatures recorded at the field sites.

\section{RESULTS}

\section{Preferred $T_{b}$}

The means of the temperatures which individual species 'select' on the thermal bar differ significantly $(\mathrm{p}<0.001)$ (Table 1). Mitopus morio accumulated at the lowest mean temperature $\left(3.4^{\circ} \mathrm{C}\right)$ with $P$. assimilis and $N$. rufescens several degrees higher. The remainder of the species had higher preferred $\mathrm{T}_{\mathrm{b}}$, with means between 12.9 and $15.5^{\circ} \mathrm{C}$.

The point of introduction on to the thermal bar had no significant effect on the final position of the species along it, except for $N$. germinyi and $M$. morio $(\mathrm{p}<0.05)$ (mean final positions $8.6,15.6,13.5^{\circ} \mathrm{C}$ and $2.5,3.6,5.4^{\circ} \mathrm{C}$ respectively, when introduced at $\mathrm{A}, \mathrm{B}, \mathrm{C}$ ). The site of collection had little effect on the final position of individuals on the thermal bar, except for summit $(1055 \mathrm{~m})$ specimens of $M$. morio in warmer temperatures (Table 2): this species also had a more variable response when collected from the two highest sites.

\section{Cold tolerance}

The mean supercooling points (SCP) differed significantly between the species tested (Table 3 and 4). The elaterid $H$. riparius had a particularly low mean of $-15.1^{\circ} \mathrm{C}$, followed by $B$. pilula at $-8.0^{\circ} \mathrm{C}$, but the other
TABLE 1. A comparison of the mean temperatures for each species of the final positions on the thermal bar in the temperature gradient experiments. $\mathrm{n}=$ number of runs contributing to the mean, ()$=$ mean number of individuals per run, $\mathrm{SE}=$ the simple average of the standard error of the least square means, $\mathrm{R}^{2}$ based on a model including species terms only.

\begin{tabular}{lcc}
\hline Species & $\begin{array}{c}\text { Mean } \\
\text { temperature }\end{array}$ & $\mathrm{n}$ \\
\hline Carabus problematicus & 15.5 & $42(1.6)$ \\
Byrrhus pilula & 14.8 & $15(5.7)$ \\
Hypnoidus riparius & 14.1 & $15(8.4)$ \\
C. problematicus larvae & 14.0 & $12(2.0)$ \\
Notiophilus germinyi & 12.9 & $12(9.3)$ \\
Nebria rufescens & 7.1 & $30(2.7)$ \\
Patrobus assimilis & 6.1 & $12(3.5)$ \\
Mitopus morio & 3.4 & $48(3.9)$ \\
\hline Average SE & 1.07 & \\
$\mathrm{R}^{2}$ & 0.541 & \\
Significance of species effect & $\mathrm{p}<0.001$ & \\
\hline
\end{tabular}

species, all carabid beetles, had similar mean SCPs, falling between -7.0 and $-5.8^{\circ} \mathrm{C}$. Only the SCPs of $H$. riparius show an elevational effect (Table 3), although those of C. problematicus tend towards significance, individuals from the middle elevation sites having lower SCPs than those from the summit. The seasonal effect on SCP (Table 4) is pronounced in the smaller carabids, $N$. rufescens and $P$. assimilis, and also in $B$. pilula; the values tend to be lower before than during winter. Using the criterion of voluntary mobility for $\geq 24 \mathrm{hr}$ following freezing, the larger carabids, $P$. adstrictus, $P$. aethiops, $P$. niger and $C$. problematicus, were freeze-tolerant, whereas the smaller species, $H$. riparius, $B$. pilula, $N$. rufescens and $P$. assimilis were freeze intolerant.

\section{Arthropod distribution}

The number of arthropods collected at the $660 \mathrm{~m}$ site was disproportionately low (Fig. 1), probably because of a lack of shelter. Differences in the distribution between the sites were significant for all species $(\mathrm{p} \leq 0.001)$. Pterostichus madidus $(\mathrm{n}=74$ at $660 \mathrm{~m}$ ) was found solely in the lowest site, whereas $P$. assimilis and $N$. rufescens were almost exclusively above it. Notiophilus germinyi and $B$. pilula gradually increased in numbers from the lowest site, whereas $H$. riparius decreased from the 860 $\mathrm{m}$ site upwards. Carabus problematicus and M. morio were fairly evenly distributed.

The adult occurrence of $N$. rufescens, B. pilula and $H$. riparius peaked in late spring, $N$. germinyi in summer and $P$. assimilis in both (Fig. 2). The peak of C. problematicus was in summer, but it spread into late spring and early autumn. The harvestman $M$. morio was distributed evenly throughout the sampling period, but included both young and adult stages.

$N$. rufescens and $P$. assimilis have high mean elevations in Britain as a whole (Table 5). As these means are for entire $\mathrm{km}$ squares, they are lower than they would be for point measurements. Carabus problematicus, N. germi- 
TABLE 2. The effect of origin (site of collection) on the final position of species on the thermal bar in the temperature gradient experiments. ( ) number of runs, temperatures in ${ }^{\circ} \mathrm{C}$.

\begin{tabular}{|c|c|c|c|c|c|c|c|c|c|}
\hline \multirow[b]{2}{*}{ Species } & \multirow[b]{2}{*}{ Means } & \multicolumn{5}{|c|}{ Origin $(\mathrm{m})$} & \multirow[b]{2}{*}{$\mathrm{SE}^{*}$} & \multirow[b]{2}{*}{$\mathrm{R}^{2}$} & \multirow[b]{2}{*}{$\mathrm{P}$} \\
\hline & & 630 & 660 & 860 & 980 & 1066 & & & \\
\hline $\begin{array}{l}\text { Carabus } \\
\text { problematicus }\end{array}$ & $\begin{array}{l}\text { Temp. } \\
\text { SD }\end{array}$ & & $\begin{array}{r}15.8(18) \\
9.2(12)\end{array}$ & $\begin{array}{c}14.7(18) \\
6.85(12)\end{array}$ & $17.6(6)$ & & $\begin{array}{l}3.01 \\
1.870\end{array}$ & $\begin{array}{l}0.009 \\
0.034\end{array}$ & $\begin{array}{l}>0.05 \\
>0.05\end{array}$ \\
\hline $\begin{array}{l}\text { larvae } \\
\text { lar }\end{array}$ & $\begin{array}{l}\text { Temp. } \\
\text { SD }\end{array}$ & & & & $\begin{array}{c}14.0(12) \\
7.91(12)\end{array}$ & & & & \\
\hline $\begin{array}{l}\text { Nebria } \\
\text { mufescens }\end{array}$ & $\begin{array}{l}\text { Temp. } \\
\text { SD }\end{array}$ & & & $\begin{array}{l}7.6(21) \\
1.52(6)\end{array}$ & $\begin{array}{l}6.2(3) \\
1.64(3)\end{array}$ & $\begin{array}{l}7.9(6) \\
3.96(6)\end{array}$ & $\begin{array}{l}1.19 \\
0.456\end{array}$ & $\begin{array}{l}0.043 \\
0.562\end{array}$ & $\begin{array}{l}>0.05 \\
<0.01\end{array}$ \\
\hline $\begin{array}{l}\text { Notiophilus } \\
\text { germinyi }\end{array}$ & $\begin{array}{l}\text { Temp } \\
\text { SD }\end{array}$ & $\begin{array}{c}13.3(6) \\
7.93(6)\end{array}$ & & & $\begin{array}{l}11.9(6) \\
9.10(6)\end{array}$ & & $\begin{array}{l}1.80 \\
1.062\end{array}$ & $\begin{array}{l}0.029 \\
0.055\end{array}$ & $\begin{array}{l}>0.05 \\
>0.05\end{array}$ \\
\hline $\begin{array}{l}\text { Patrobus } \\
\text { assimilis }\end{array}$ & $\begin{array}{l}\text { Temp. } \\
\text { SD }\end{array}$ & & & $\begin{array}{l}6.1(12) \\
5.18(12)\end{array}$ & & & & & \\
\hline $\begin{array}{l}\text { Byrrhus } \\
\text { pilula }\end{array}$ & $\begin{array}{l}\text { Temp. } \\
\text { SD }\end{array}$ & $\begin{array}{c}16.9(3) \\
8.20(3)\end{array}$ & & $\begin{array}{l}10.4(3) \\
8.96(3)\end{array}$ & $\begin{array}{c}17.3(3) \\
8.65(3)\end{array}$ & $\begin{array}{c}11.5(6) \\
7.70(6)\end{array}$ & $\begin{array}{l}2.23 \\
1.516\end{array}$ & $\begin{array}{l}0.459 \\
0.036\end{array}$ & $\begin{array}{l}>0.05 \\
>0.05\end{array}$ \\
\hline $\begin{array}{l}\text { Hypnoidus } \\
\text { riparius }\end{array}$ & $\begin{array}{l}\text { Temp. } \\
\text { SD }\end{array}$ & $\begin{array}{c}11.0(3) \\
4.74(3)\end{array}$ & & $\begin{array}{c}14.2(3) \\
5.52(3)\end{array}$ & $\begin{array}{c}14.4(6) \\
6.14(6)\end{array}$ & $\begin{array}{c}15.6(3) \\
4.31(3)\end{array}$ & $\begin{array}{l}3.02 \\
1.51\end{array}$ & $\begin{array}{l}0.074 \\
0.095\end{array}$ & $\begin{array}{l}>0.05 \\
>0.05\end{array}$ \\
\hline $\begin{array}{l}\text { Mitopus } \\
\text { morio }\end{array}$ & $\begin{array}{l}\text { Temp. } \\
\text { SD }\end{array}$ & & $\begin{array}{l}2.5(12) \\
3.15(12)\end{array}$ & $\begin{array}{l}2.2(12) \\
3.57(12)\end{array}$ & $\begin{array}{l}2.7(12) \\
5.80(12)\end{array}$ & $\begin{array}{l}6.2(12) \\
5.96(12)\end{array}$ & $\begin{array}{l}0.88 \\
0.890\end{array}$ & $\begin{array}{l}0.234 \\
0.161\end{array}$ & $\begin{array}{l}<0.01 \\
=0.05\end{array}$ \\
\hline
\end{tabular}

*average standard error of the mean

nyi and M. morio have lower mean elevations. No British distributional data were available for $B$. pilula or $H$. riparius.

\section{Site temperatures}

There was significant correlation $(p<0.01)$ between sites and maximum temperature. Although the higher sites tended to have lower maximum temperatures (Fig. 3 ), the $860 \mathrm{~m}$ site was coldest. The range of maxima between sites, for a particular 14 day period, varied from $10^{\circ} \mathrm{C}$ in August to $2^{\circ} \mathrm{C}$ in early October. The minimum temperatures were more in order of elevation, but the highest site $(1055 \mathrm{~m})$ was significantly warmer than the second highest $(980 \mathrm{~m})(\mathrm{p}<0.001)$. The range varied from about 5 to $1^{\circ} \mathrm{C}$. The coldest winter temperature $\left(-6.3^{\circ} \mathrm{C}\right)$ was recorded in the second lowest site $(860 \mathrm{~m})$.

During the example of a sunny day (Fig. $4 \mathrm{a}$ ), the maximum, minimum and widest range of temperature $\left(16^{\circ} \mathrm{C}\right)$



Fig. 1. The elevational distribution (\% combined catch in 1989 and 1990) of arthropod species collected by pitfall trapping at four sites on Snowdon. The complete comparison is significant at $\mathrm{P}<0.001$ in all cases. The number of individuals of each species collected is shown in parentheses in the key. 
TABLE 3. The effect of elevation on the supercooling point (SCP) of various arthropods. ()$=\mathrm{n}$, temperatures in ${ }^{\circ} \mathrm{C} .{ }^{*}=$ species included in preferred $\mathrm{T}_{\mathrm{b}}$ experiment

\begin{tabular}{|c|c|c|c|c|c|c|c|}
\hline \multirow{2}{*}{ Species } & \multirow{2}{*}{ Means } & \multirow{2}{*}{$\begin{array}{l}\text { Mean SCP } \\
\text { (all sites) }\end{array}$} & \multicolumn{4}{|c|}{ Mean SCP at sites at various elevations (m) } & \multirow{2}{*}{$\begin{array}{c}\text { Significance } \\
\text { of site effect } \\
\text { P }\end{array}$} \\
\hline & & & 660 & 860 & 950 & 1055 & \\
\hline *Carabus problematicus & $\begin{array}{l}\text { Temp } \\
\text { SD }\end{array}$ & $\begin{array}{l}-5.8(37) \\
1.98\end{array}$ & & $\begin{array}{c}-6.8(9) \\
0.63\end{array}$ & $\begin{array}{l}-6.5(6) \\
0.77\end{array}$ & $\begin{array}{l}-5.2(22) \\
0.40\end{array}$ & 0.07 \\
\hline *Nebria rufescens & $\begin{array}{l}\text { Temp } \\
\text { SD }\end{array}$ & $\begin{array}{l}-6.9(42) \\
1.68\end{array}$ & & $\begin{array}{l}-6.4(12) \\
0.48\end{array}$ & $\begin{array}{l}-6.8(8) \\
0.59\end{array}$ & $\begin{array}{l}-7.3(22) \\
0.35\end{array}$ & 0.27 \\
\hline *Patrobus assimilis & $\begin{array}{l}\text { Temp } \\
\text { SD }\end{array}$ & $\begin{array}{l}-6.1(38) \\
2.41\end{array}$ & & & $\begin{array}{c}-6.2(15) \\
0.63\end{array}$ & $\begin{array}{c}-6.1(23) \\
0.51\end{array}$ & 0.90 \\
\hline *Byrrhus pilula & $\begin{array}{l}\text { Temp } \\
\text { SD }\end{array}$ & $\begin{array}{l}-8.0(13) \\
4.80\end{array}$ & & $\begin{array}{l}-8.7(5) \\
2.04\end{array}$ & $\begin{array}{c}-11.2(3) \\
2.63\end{array}$ & $\begin{array}{c}-5.3(5) \\
2.04\end{array}$ & 0.24 \\
\hline *Hypnoidus riparius & $\begin{array}{l}\text { Temp } \\
\text { SD }\end{array}$ & $\begin{array}{c}-15.1(7) \\
4.84\end{array}$ & & & $\begin{array}{c}-17.8(5) \\
0.83\end{array}$ & $\begin{array}{l}-8.5(2) \\
1.32\end{array}$ & $<0.01$ \\
\hline Pterostichus aethiops & $\begin{array}{l}\text { Temp } \\
\text { SD }\end{array}$ & $\begin{array}{l}-5.8(9) \\
0.79\end{array}$ & & & $\begin{array}{l}-6.0(3) \\
0.48\end{array}$ & $\begin{array}{c}-5.8(6) \\
0.34\end{array}$ & 0.69 \\
\hline Pterostichus adstrictus & $\begin{array}{l}\text { Temp } \\
\text { SD }\end{array}$ & $\begin{array}{c}-6.8(8) \\
2.59\end{array}$ & $\begin{array}{c}-6.1(5) \\
1.16\end{array}$ & & & $\begin{array}{c}-8.0(3) \\
1.49\end{array}$ & 0.35 \\
\hline Pterostichus niger & $\begin{array}{l}\text { Temp } \\
\text { SD }\end{array}$ & $\begin{array}{l}-5.8(8) \\
0.99\end{array}$ & $\begin{array}{c}-5.8(8) \\
0.99\end{array}$ & & & & \\
\hline Pooled SD & & 2.48 & 1.17 & 3.18 & 1.82 & 2.17 & \\
\hline $\begin{array}{l}\text { Significance of species } \\
\text { effect }\end{array}$ & & $\mathrm{p}<0.01$ & $\mathrm{p}=0.68$ & $\mathrm{p}=0.39$ & $\mathrm{p}<0.01$ & $\mathrm{p}<0.01$ & \\
\hline
\end{tabular}

were in the turf in the sun. The highest night-time, lowest day-time and least range of temperatures were under the boulder: the shade temperatures were similar. The maximum difference at one time was $9^{\circ} \mathrm{C}$. On the cloudy day (Fig. 4b), the range was only $3.5^{\circ} \mathrm{C}$; least fluctuation was again under the boulder.

\section{Correlation between preferred $T_{b}$, cold tolerance and British distribution}

There is a significant correlation between preferred $T_{b}$ and the mean elevation of the $\mathrm{km}^{2}$ cells in Britain in which the species had been recorded (Table 6). The correlation between preferred $\mathrm{T}_{\mathrm{b}}$ and mean summer and winter

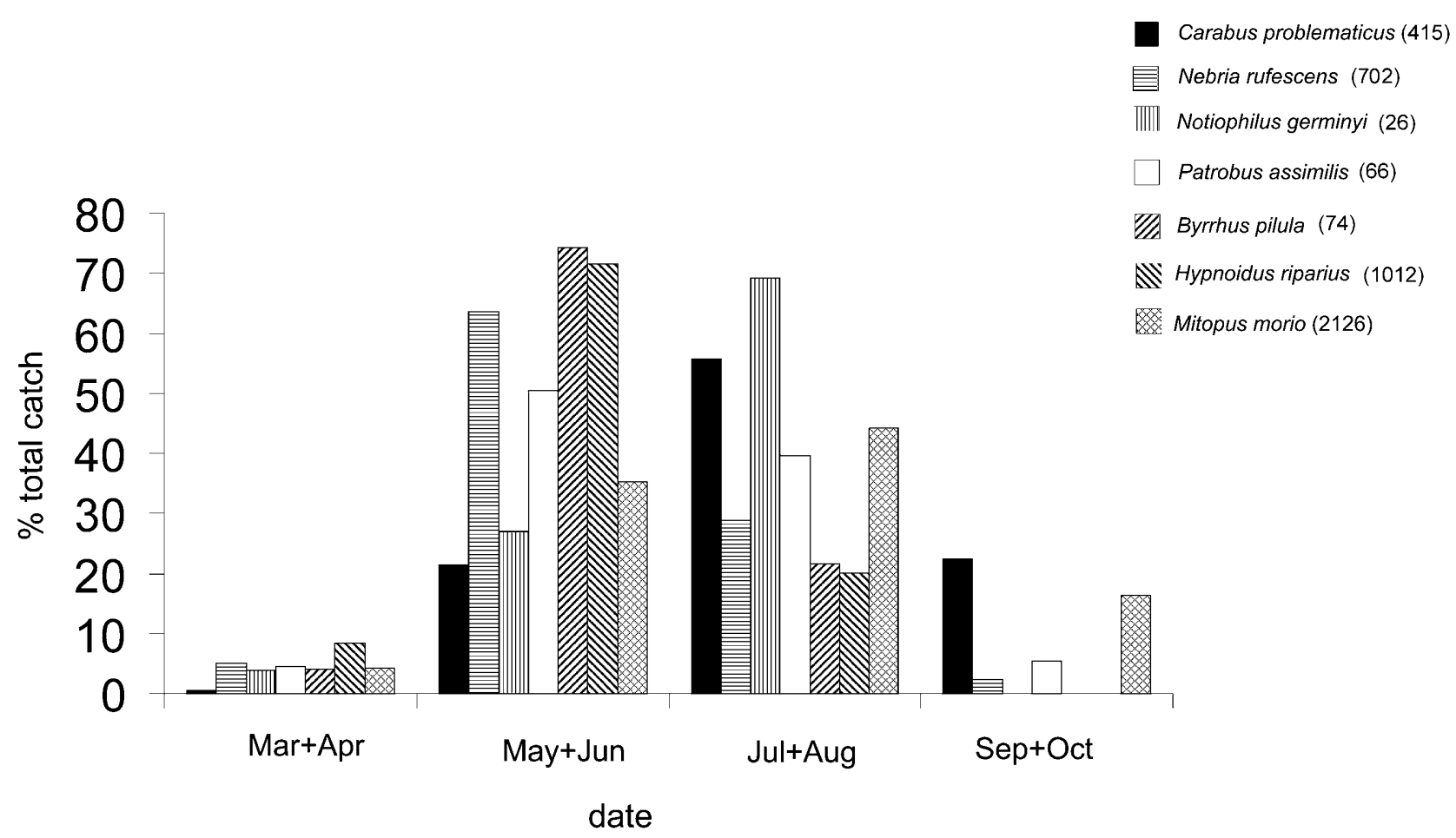

Fig. 2. The temporal distribution (\% total catch in 1990) of arthropod species collected by pitfall trapping on Snowdon. The number of individuals of each species collected is shown in the key. 
TABLE 4. The effect of season on the supercooling point (SCP) of various arthropods. ()$=\mathrm{n}$, temperatures in ${ }^{\circ} \mathrm{C}$. $*=$ species included in preferred $\mathrm{T}_{\mathrm{b}}$ experiment.

\begin{tabular}{|c|c|c|c|c|c|c|}
\hline \multirow{2}{*}{ Species } & & \multirow{2}{*}{$\begin{array}{l}\text { Mean SCP } \\
\text { (all dates) }\end{array}$} & \multicolumn{3}{|c|}{ Mean SCP on date tested } & \multirow{2}{*}{$\begin{array}{c}\text { Significance of } \\
\text { seasonal effect } \\
\text { P }\end{array}$} \\
\hline & & & June 1994 & Sept. 1994 & Feb. 1995 & \\
\hline *Carabus problematicus & $\begin{array}{l}\text { Temp } \\
\text { SD }\end{array}$ & $\begin{array}{l}-5.8(37) \\
1.98\end{array}$ & $\begin{array}{l}-6.3(18) \\
0.45\end{array}$ & $\begin{array}{l}-5.6(18) \\
0.45\end{array}$ & $\begin{array}{l}-2.5(1) \\
1.92\end{array}$ & 0.14 \\
\hline *Nebria rufescens & $\begin{array}{l}\text { Temp } \\
\text { SD }\end{array}$ & $\begin{array}{l}-7.0(42) \\
1.68\end{array}$ & $\begin{array}{l}-7.5(25) \\
0.28\end{array}$ & $\begin{array}{l}-7.0(11) \\
0.42\end{array}$ & $\begin{array}{l}-4.7(6) \\
0.57\end{array}$ & $<0.01$ \\
\hline *Patrobus assimilis & $\begin{array}{l}\text { Temp } \\
\text { SD }\end{array}$ & $\begin{array}{l}-6.1(38) \\
2.41\end{array}$ & $\begin{array}{c}-7.8(6) \\
0.61\end{array}$ & $\begin{array}{c}-8.2(12) \\
0.43\end{array}$ & $\begin{array}{l}-4.3(20) \\
0.33\end{array}$ & $<0.01$ \\
\hline *Byrrhus pilula & $\begin{array}{l}\text { Temp } \\
\text { SD }\end{array}$ & $\begin{array}{l}-8.0(13) \\
4.8\end{array}$ & $\begin{array}{l}-9.1(11) \\
1.21\end{array}$ & & $\begin{array}{c}-1.5(2) \\
2.85\end{array}$ & 0.03 \\
\hline *Hypnoidus riparius & $\begin{array}{l}\text { Temp } \\
\text { SD }\end{array}$ & $\begin{array}{c}-15.1(7) \\
4.85\end{array}$ & & $\begin{array}{c}-15.1(7) \\
4.85\end{array}$ & & \\
\hline Pterostichus aethiops & $\begin{array}{l}\text { Temp } \\
\text { SD }\end{array}$ & $\begin{array}{c}-5.8(9) \\
0.79\end{array}$ & & $\begin{array}{c}-5.8(9) \\
0.79\end{array}$ & & \\
\hline Pterostichus adstrictus & $\begin{array}{l}\text { Temp } \\
\text { SD }\end{array}$ & $\begin{array}{c}-6.8(8) \\
2.59\end{array}$ & $\begin{array}{l}-8.0(1) \\
2.84\end{array}$ & $\begin{array}{c}-8.0(2) \\
2.01\end{array}$ & $\begin{array}{l}-6.1(5) \\
1.27\end{array}$ & 0.67 \\
\hline Pterostichus niger & $\begin{array}{l}\text { Temp } \\
\text { SD }\end{array}$ & $\begin{array}{l}-5.8(8) \\
0.99\end{array}$ & & $\begin{array}{c}-5.8(6) \\
0.44\end{array}$ & $\begin{array}{c}-6.0(2) \\
0.76\end{array}$ & 0.78 \\
\hline Pooled SD & & 2.48 & 2.34 & 2.26 & 1.27 & \\
\hline $\begin{array}{l}\text { Significance of species } \\
\text { effect }\end{array}$ & & $\mathrm{P}<0.01$ & $\mathrm{P}=0.02$ & $\mathrm{P}<0.01$ & $\mathrm{P}<0.01$ & \\
\hline
\end{tabular}

temperatures also tends towards significance $(\mathrm{p}=0.08)$. There is no correlation between SCP of the species and the environmental factors related to their British distribution. As might be expected, winter and summer temperatures are correlated with elevation.

\section{DISCUSSION}

The relationship between the distribution of arthropod species and elevation (Fig. 1) was not clear-cut, partly because the selected elevational gradient was not a simple temperature gradient. One of the lower sites was significantly colder than the higher sites (Fig. 3), probably because of greater wind chill. The Snowdon and British



Fig. 3. The maximum temperature (-) and the minimum temperature (- - - ) recorded at four sites of increasing elevation during fortnightly periods in 1990. The maximum and minimum temperature at each site during the winter of $1990-1991$ are also shown. Recordings were in shaded turf. There was significant correlation between site and maximum and minimum temperatures $(\mathrm{p}<0.01$ and $\mathrm{p}<0.001$ respectively). 
TABLE 5. The relationship of some arthropod species with the mean elevation, temperature and sunshine of the $\mathrm{km}^{2}$ cells in Britain in which they had been recorded. All the species are included in the preferred $T_{b}$ experiment.

\begin{tabular}{lcccc}
\hline Species & $\begin{array}{c}\text { Mean } \\
\text { elevation } \\
(\mathrm{m})\end{array}$ & $\begin{array}{c}\text { Mean } \\
\text { winter } \\
\text { tempera- } \\
\text { ture } \\
\left({ }^{\circ} \mathrm{C}\right)\end{array}$ & $\begin{array}{c}\text { Mean } \\
\text { summer } \\
\text { tempera- } \\
\text { ture } \\
\left({ }^{\circ} \mathrm{C}\right)\end{array}$ & $\begin{array}{c}\text { Mean } \\
\text { sunshine } \\
(\mathrm{hr} / \text { day })\end{array}$ \\
\hline Carabus problematicus & 188 & 3.0 & 13.1 & 3.4 \\
Mitopus morio & 150 & 3.1 & 13.6 & 3.6 \\
Nebria rufescens & 260 & 2.3 & 12.2 & 3.2 \\
Notiophilus germinyi & 186 & 3.1 & 13.3 & 3.5 \\
Patrobus assimilis & 288 & 2.4 & 12.2 & 3.1 \\
\hline
\end{tabular}

elevational distribution (Fig. 1 and Table 5) of N. rufescens and P. assimilis, both northern British species (Lindroth, 1974), suggest that they are both alpine species. The remainder, such as C. problematicus, are upland species that extend into the alpine zone. Pterostichus madidus (Fabricius), found only at our lowest site, extends upwards from urban gardens (Lindroth, 1974). The harvestman Mitopus morio is ubiquitous in Britain (thus explaining the lower mean elevation in Table 5), occurring up to $3000 \mathrm{~m}$ in Europe (Hillyard \& Sankey, 1989). It has, however, various upland varieties, such as M. morio alpinus (Herbst) and, in Britain, M. morio ericaeus Jennings (Hillyard \& Sankey, 1989).

The alpine $N$. rufescens and $P$. assimilis had lower preferred $\mathrm{T}_{\mathrm{b}}$ (7.1 and 5.6 respectively) than wide-ranging species such as C. problematicus $\left(15.5^{\circ} \mathrm{C}\right)$. Krogerus' (1960) value of $8^{\circ} \mathrm{C}$ for $N$. rufescens suggests that preferred $T_{b}$ is broadly constant for individual species. The lowest mean preferred $\mathrm{T}_{\mathrm{b}}\left(3.4^{\circ} \mathrm{C}\right)$ was for Mitopus morio; an earlier value of $11.8^{\circ} \mathrm{C}$ (Todd, 1949) suggests that it differs between upland and lowland varieties. The alpine species, being crepuscular, were active when the mean site temperatures were $4.5^{\circ} \mathrm{C}$ and $4.6^{\circ} \mathrm{C}$, at $980 \mathrm{~m}$ and $1055 \mathrm{~m}$ respectively (Fig. 3 ), close to their preferred $\mathrm{T}_{\mathrm{b}}$. The low mean temperatures for their British distribution (Table 5) were less clear because such records are compiled on a $\mathrm{km}^{2}$ basis. Although the complex temperature regime precluded significant correlation between pre-

TABLE 6. The results of the Pearson correlation between preferred $T_{b}$, SCP, and environmental parameters of the $\mathrm{km}^{2}$ cells in Britain in which the selected species (see Table 5) have been recorded.

\begin{tabular}{llrrrr}
\hline & & $\begin{array}{c}\text { Pre- } \\
\text { ferred } \\
\mathrm{T}_{\mathrm{b}}\end{array}$ & $\mathrm{SCP}$ & $\begin{array}{c}\text { Eleva- } \\
\text { tion }\end{array}$ & $\begin{array}{c}\text { Winter } \\
\text { tem- } \\
\text { pera- } \\
\text { ture }\end{array}$ \\
\hline SCP & $\begin{array}{l}\text { Pearson correlation } \\
\text { Elevation }\end{array}$ & 0.585 & & & \\
& Significance $(\mathrm{p})$ & 0.602 & & & \\
Winter & Pearson correlation & -0.967 & -0.472 & & \\
& Significance (p) & 0.033 & 0.687 & & \\
temperature & Pearson correlation & 0.920 & 0.782 & -0.945 & \\
Summer & Pearson correlation & 0.924 & 0.693 & -0.968 & 0.994 \\
temperature Significance (p) & 0.076 & 0.512 & 0.032 & 0.006 \\
\hline
\end{tabular}

ferred $T_{b}$ and increasing elevation on Snowdon (Table 2), this relationship was significant for Britain as a whole (Table 6), supporting the hypothesis that species at higher elevations had lower preferred $T_{b}$ than those at lower elevations. Correlation of preferred $T_{b}$ with winter and summer temperatures also tended towards significance.

In winter, survival depends on cold tolerance. Surprisingly, there was little difference in mean SCP ( -5.8 to $-8.0^{\circ} \mathrm{C}$ ) between the smaller alpine and the larger upland species (Table 3 ). (Adult $H$. riparius had an exceptionally low SCP of $-15^{\circ} \mathrm{C}$, but do not overwinter.) In this study, SCP tended to rise from June to February (Table 4); generally it decreases in winter, e.g. by $6^{\circ} \mathrm{C}$ in the arctic Pterostichus brevicornis (Baust \& Miller, 1970). Minimum temperatures $\left(-6^{\circ} \mathrm{C}\right)$ in turf in the winter of 1990 (Fig. 3) were close to the highest SCP. Air temperatures at the summit during the cold tolerance experiment fell to $-8.0^{\circ} \mathrm{C}$, the minimum for $1994-2000$ being $-12^{\circ} \mathrm{C}$ (J. Williams, pers. com.). Snow is a good insulator (e.g. Sømme, 1982, 1999: Danks, 2000), for example, the temperature at $10 \mathrm{~cm}$ soil depth was $1.1^{\circ} \mathrm{C}$ when air temperature was $-9.2^{\circ} \mathrm{C}$ (Danks 1991), but, as it is infrequent on Snowdon, overwintering arthropods are subject to continuously changing soil temperature profile as air temperature changes. The turf provides some protection; Rosenberg (1974) reports the equivalent of $-10^{\circ} \mathrm{C}$ at $1 \mathrm{~cm}$ and $-6^{\circ} \mathrm{C}$ at $40 \mathrm{~cm}$ in bare ground being $-7^{\circ} \mathrm{C}$ and $-3^{\circ} \mathrm{C}$ under turf. The small size of the freeze intolerant alpine species suggests that they survive on Snowdon because they penetrate the soil. Their slightly lower mean SCP, as normal for freeze intolerant species (Sømme, 1999), adds further protection, but fatalities may occur above this as lethal temperatures above SCP were not investigated. The freeze tolerance of the larger carabids may contribute to their more widespread distribution. Their lowest lethal temperatures were not measured and so may be below SCP. However, as few British insects are freeze tolerant (Hart \& Bale, 1997), further examination of these large carabids would be worthwhile.

The alpine species survive on Snowdon because of the lower preferred/optimal $\mathrm{T}_{\mathrm{b}}$ at higher elevations, as hypothesised, and their ability to tolerate winter temperatures. Their response, however, is not solely to temperature, but to the whole gamut of environmental conditions (Cossins \& Bowler, 1987), including available shelter and competing/enemy species (Davis et al., 1998). The advantages of proximity to the optimal $\mathrm{T}_{\mathrm{b}}$ are illustrated by the widespread C. problematicus having a life-cycle of one year at lower elevations, where ambient temperatures are close to its preferred $\mathrm{T}_{\mathrm{b}}\left(\mathrm{c} .15^{\circ} \mathrm{C}\right)$, but two years at higher elevations where they are lower (Butterfield, 1986; Sparks et al., 1995). The hypothesis that there is greater cold tolerance at higher elevations is rejected as the SCP was similar in both alpine and wide-ranging species. The alpine species were freeze-intolerant, depending on shelter to protect them from cold, whereas the wideranging species were, by the criteria used in this study, freeze-tolerant. The close relationship identified in this study between arthropod species and temperature sug- 


\section{a. Sunny}

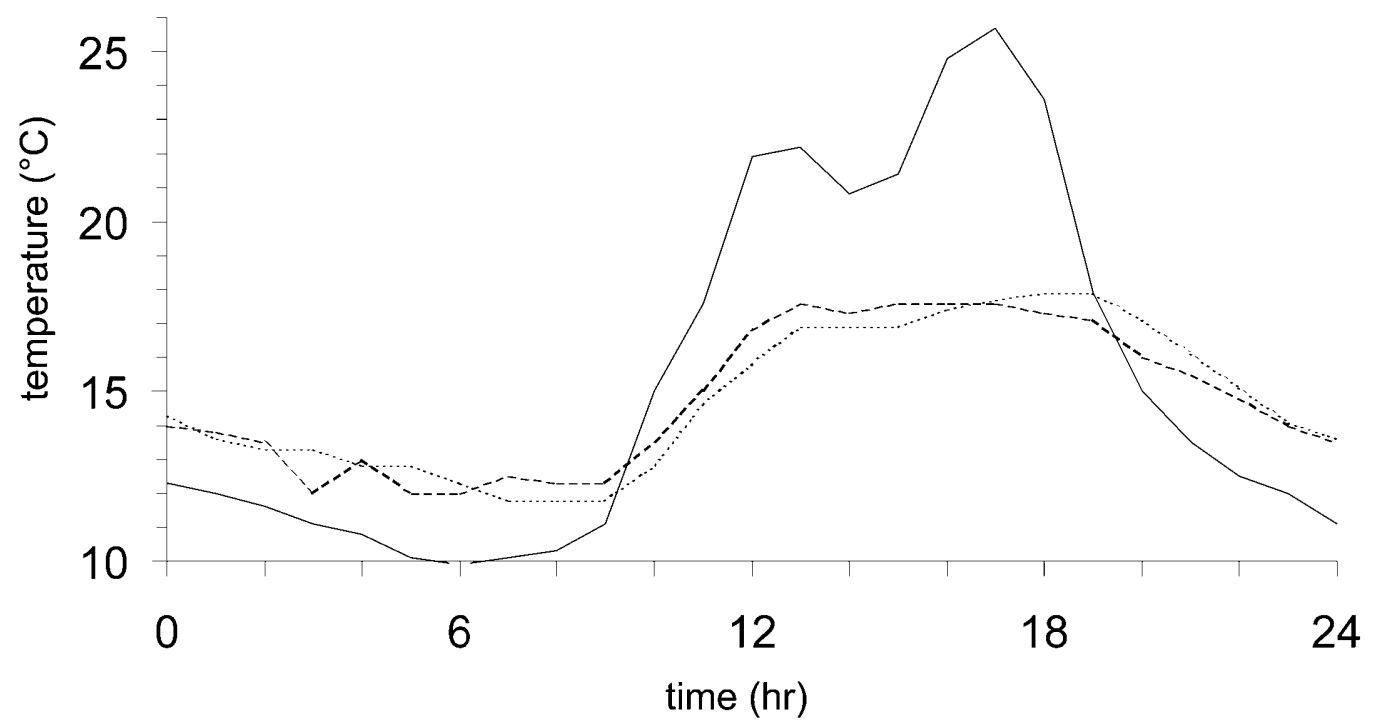

b. Cloudy

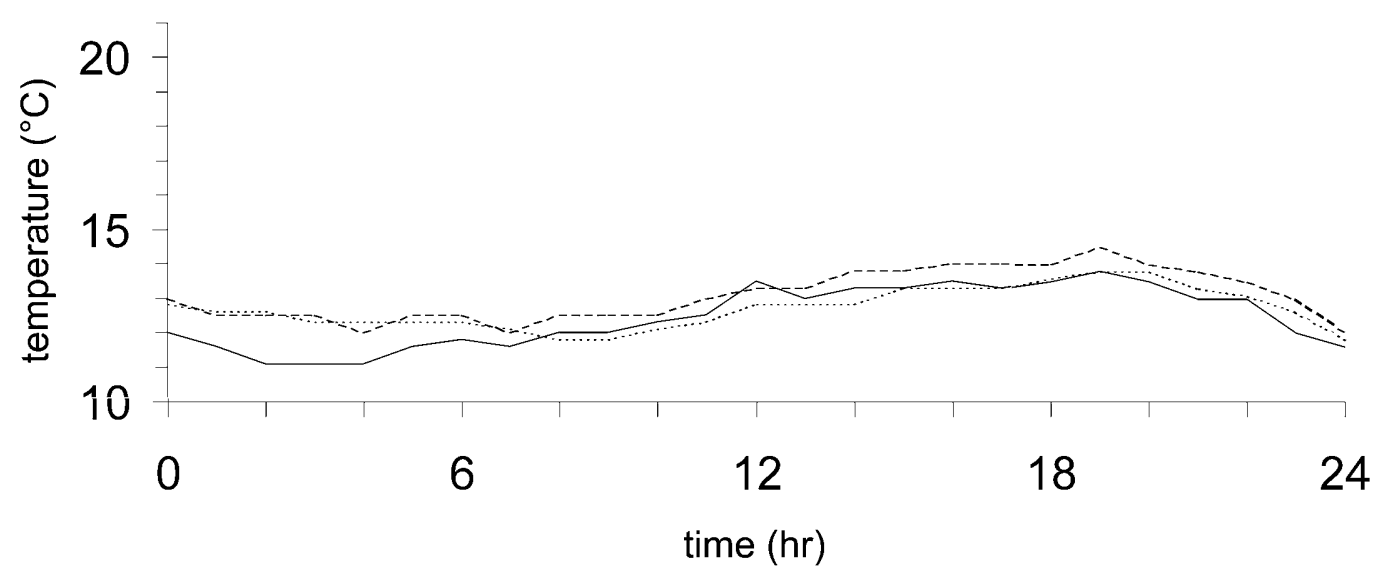

Fig. 4. The temperatures recorded at the $660 \mathrm{~m}$ site during contrasting sunny and cloudy days (7 and 13 September 1991) in turf in shade (- - $)$ ) and in sun (-), and under a boulder (- - - - -).

gests that the expected shift of temperature zones with global climate change will lead to movement of species to higher elevations, with the loss of sensitive species (Brown, 1992). However, it also confirms that current species' distributions, because of their underlying complexity, are no guide to what they might be under global climate change (Davis et al., 1998).

ACKNOWLEDGEMENTS. We wish to thank the following CEH staff: A.G. Thomson, A.A. Bell and J. Potts, for their assistance with the field collections, and R. Rafarel for designing and $\mathrm{G}$ Hughes for constructing the thermal bar. We are grateful to W. Block, R. Worland and P. Montiel, at the British Antarctic Survey, Cambridge, for their advice and assistance during the cold tolerance studies.

\section{REFERENCES}

ADIS J. 1979: Problems of interpreting arthropod sampling with pitfall traps. Zool. Anz. 202: 177-184.
Andrewartha H.G. \& Birch L.C. 1954: The Distribution and Abundance of Animals. University of Chicago Press, Chicago, $782 \mathrm{pp}$.

BaLe J.S. 1993: Classes of insect cold hardiness. Func. Ecol. 7: 751-753.

Baust J.G. \& Miller L.K. 1970: Variations in glycerol content and its influence on cold hardiness in the Alaskan carabid beetle, Pterostichus brevicornis. J. Insect Physiol. 16: 979-990.

Begon M., Harper J.L. \& Townsend C.R. 1990: Ecology: Individuals, Populations and Communities. Blackwell, Boston, $945 \mathrm{pp}$.

BiRKs H.J.B. 1988: Long-term ecological change in the British uplands. In Usher M.B. \& Thompson D.B.A. (eds): Ecological Change in the Uplands. Blackwell, Oxford, pp. 37-56.

BLOCK W. 1990: Cold tolerance of insects and other arthropods. Phil. Trans. R. Soc. Lond. B 326: 613-633.

Brown A. (ed.) 1992: The UK Environment. HMSO, London, $258 \mathrm{pp}$. 
Buse A. 1988: Habitat selection and grouping of beetles (Coleoptera). Holarct. Ecol. 11: 241-247.

ButTerfield J.E.L. 1986: Changes in life-cycle strategies of Carabus problematicus over a range of altitudes in northern England. Ecol. Entomol. 11: 17-26.

Campbell S. \& Bowen D.Q. 1989: Geological Conservation Review: Quaternary of Wales. Nature Conservancy Council, Peterborough, $237 \mathrm{pp}$.

Christie G.C. \& Regier H.A. 1988: Measures of optimal thermal habitat for four commercial fish species. Can. J. Fish. Aquat. Sci. 45: 301-314.

Cossins A.R. \& Bowler K. 1987: Temperature Biology of Animals. Chapman and Hall, London, $339 \mathrm{pp}$.

DANKS H.V. 1991: Winter habitats and ecological adaptations for winter survival. In Lee R.E. \& Denlinger D.L. (eds) Insects at Low Temperature. Chapman and Hall, New York, pp. 231-259.

DANKS H.V. 2000: Insect cold hardiness: a Canadian perspective. CryoLetters 21: 297-308.

Davis A.J., Lawton J.H., Shorrocks B. \& JenKinson L.S. 1998 Individualistic species responses invalidate simple physiological models of community dynamics under global environmental change. J. Anim. Ecol. 67: 600-612.

Halsall N.B. \& Wratten S.D. 1988: The efficiency of pitfal trapping for polyphagous predatory Carabidae. Ecol. Entomol. 13: 293-299.

Hart A.J. \& Bale J.S. 1997: Evidence for the first strongly freeze-tolerant insect found in the U.K. Ecol. Entomol. 22 242-245.

Herter K. 1926: Thermotaxis und Hydrotaxis bei Tieren. Bethes. Handb. Norm. Path. Physiol. 11: 173-180.

HeRTER K. 1953: Der Temperatursinn der Insekten. Duncker and Humblot, Berlin, 378 pp.

Hillyard P.D. \& Sankey J.H.P. 1989: Harvestmen. Synopses Br. Fauna 4: 1-119.

IPCC 1996: Climate Change 1995: The Science of Climate Change. Houghton J.T., Filho L.G.M., Callander B.A., Harris N., Kattenberg A. \& Maskell K. (eds): University Press, Cambridge, $572 \mathrm{pp}$.

Krogerus R. 1960: Ökologische Studien über nordische Moorarthropoden. Commentat. Biol. 21 (3): 1-238

Laudien H. 1973: Activity, behaviour etc. In Precht H., Christopherson J., Hensel H. \& Larcher W. (eds): Temperature and Life. Springer-Verlag, Berlin, pp. 441-469.

LAWTON J.H. 1995: The response of insects to environmental change. In Harrington R. \& Stork N.E. (eds): Insects in a Changing Environment. Academic Press, London, pp. 3-26.

Leather S.R., Walters K.F.A. \& Bale J.S. 1993: The Ecology of Insect Overwintering. Cambridge University Press, Cambridge, $255 \mathrm{pp}$.

Lee R.E. \& Denlinger D.L. (eds) 1991: Insects at Low Temperature. Chapman and Hall, New York, 513 pp.

LenNon J.L. \& Turner J.R.G. 1995: Predicting the spatial distribution of climate: temperature in Great Britain. J. Anim. Ecol. 64: $370-392$.

Lindroth C.H. 1974: Coleoptera: Carabidae. Handbk. Ident. Br. Insects 4 (2), $148 \mathrm{pp}$.

LuFF M.L. 1965: The morphology and microclimate of Dactylis glomerata tussocks. J. Ecol. 53: 771-787.

LUFF M.L. 1998: Provisional Atlas of the Ground Beetles (Coleoptera, Carabidae) of Britain. Biological Records Centre, Huntingdon, $194 \mathrm{pp}$.

MANI M.S. 1980: The animal life of highlands. In Mani M.S. \& Giddings L.E. (eds): Ecology of Highlands. Junk, The Hague, pp. 141-159.
Mani M.S. \& GdDdngs L.E. 1980: Ecology of Highlands. Junk, The Hague, 249 pp.

$\emptyset_{\mathrm{StBYE}}$ E. 1969: Records of Coleoptera from the Finse area. Norsk Entomol. Tidsskr. 16: 41-43.

OTteSEN P.S. 1985: Diel activity patterns of South Scandinavian high mountain ground beetles (Coleoptera, Carabidae). Holarct. Ecol. 8: 191-203.

PARMesan C. 1996: Climate and species' range. Nature $\mathbf{3 8 2}$ 765-766.

Parmesan C., Rrrholm N., Stefanescu C., Hill J.K., Thomas C.D., Descrmon H., Huntley B., Kaila L., Kulberg J., Tammaru T., Tennent W.J., Thomas J.A. \& Warren M. (1999): Poleward shifts in geographical ranges of butterfly species associated with regional warming. Nature 399: 579-583.

PerKINs D.F. 1978: Snowdonia grassland: introduction, vegetation and climate. In Heal O.W. \& Perkins D.F. (eds): Production Ecology of British Moors and Grasslands. Springer-Verlag, Berlin, pp. 375-395.

RatCliffe D.A. \& Thompson D.B.A. 1988: The British uplands: their ecological character and international significance. In Usher M.B. \& Thompson D.B.A. (eds): Ecological Change in the Uplands. Blackwell, Oxford, pp. 9-36.

RoSENBERG N.J. 1974: Microclimate: the Biological Environment. Wiley, New York, 315 pp.

SinCLAIR B.J. 1999: Insect cold tolerance: how many kinds of frozen? Eur. J. Entomol. 96: 157-164.

Solhøy T., Østbye E., Kauri H., Hagen A., Lien L. \& Skar H.-J. 1975: Faunal structure of Hardangervidda, Norway. In Wielgolaski F.E. (ed.): Fennoscandian Tundra Ecosystems. Part 2: Animals and Systems Analysis. Springer-Verlag, Berlin, pp. 27-45.

SøMME L. 1982: Supercooling and winter survival in terrestrial arthropods. Comp. Biochem. Physiol. (A) 73: 519-543.

Sømme L. 1999: The physiology of cold hardiness in terrestrial arthropods. Eur. J. Entomol. 96: 1-10.

Sparks T.H., Buse A. \& Gadsden R.J. 1995: Life strategies of Carabus problematicus (Coleoptera, Carabidae) at different altitudes on Snowdon, North Wales. J. Zool. Lond. 236: 1-10.

Strathdee A.T. \& Bale J.S. 1998: Life on the edge: insect ecology in arctic environments. Annu. Rev. Entomol. 43: 85-106.

ThIELE H.-U. 1964: Experimentelle Untersuchungen über die Ursachen der Biotopbindung bei Carabiden. Z. Morph. Ökol. Tiere 53: 387-452.

Threle H.-U. 1977: Carabid Beetles in their Environments. A Study on Habitat Selection by Adaptations in Physiology and Behaviour. Springer-Verlag, Berlin, $369 \mathrm{pp}$.

Thiele H.-U. \& Lemmann, H. 1967: Analyse und Synthese im tierokölogischen Experiment. Z. Morph. Ökol. Tiere 58: 373-380.

Thompson D.B.A. \& Brown A. 1992: Biodiversity in montane Britain: habitat variation, vegetation diversity and some objectives for conservation. Biodiversity and Conservation 1: 179-208.

Tond V. 1949: The habits and ecology of the British harvestmen (Arachnida, Opiliones), with special reference to those in the Oxford district. J. Anim. Ecol. 18: 209-229.

UVArov B.P. 1931: Insects and climate. Trans. R. Entomol. Soc. Lond. 79: 1-247.

Worland R., Block W. \& Rothery P. 1992: Survival of subzero temperatures by two South Georgian beetles (Coleoptera, Perimylopidae). Polar Biol. 11: 607-613.

VANDENBERGHe E. 1992: On pitfall trapping invertebrates. Entomol. News 103: 149-156.

Received September 25, 2000; revised April 2, 2001; accepted May 21, 2001 